\title{
SATU INJIL BAGI SEGALA BUDAYA
}

\author{
Cornelis J. Haak \\ Sekolah Tinggi Teologi Aletheia \\ haakcj48@gmail.com
}

\begin{abstract}
Submit: 31-10-2021 Review: 29-11, 23-12-2021 Revisi: 21-12-2021
Diterima: 24-04-2021 Layout: 25-12-2021 Terbit: 27-12-2021
\end{abstract}

\begin{abstract}
This article explains the need the development of Reformed theology so that it can attract the attention of different cultured people with Guilt Culture. It turns out the gospel applies to all cultures, but theology of Reformed raises Luther's question that is looking for an answer about the basis of salvation. Even though it strongly agreed that the Bible was teaching that it was dismissed by justification through faith, but the recognition of 'Sola Fide' did not contain the overall gospel. Therefore, the meaning and impact of the gospel should be presented to a shame culture and a fear culture (Fear Culture) in more suitable to the questions and struggle that contexts. if characteristic every culture is more regularly understood, it can also read the Bible and the teachings of the gospel with 'lens' which are more in line with those cultural needs. With this the good news of the Gospel will get stronger to convince the listeners of the gospel.
\end{abstract}

Keywords: Covenant theology, Guilt culture, Shame culture, Fear Culture, (re-)

contextualization, tri-cultural theological concepts

\begin{abstract}
Abstrak
Artikel ini menjelaskan perlunya mengembangkan teologi reformed supaya dapat menarik perhatian orang yang berbudaya berbeda dengan budaya bersalah (guilt culture). Ternyata Injil berlaku untuk segala budaya, akan tetapi teologi reformed menimbulkan pertanyaan Luther yang mencari jawab tentang dasar keselamatan. Sekalipun sangat setuju bahwa Alkitab mengajar bahwa diselamatkan oleh pembenaran melalui iman, namun pengakuan 'Sola Fide' itu tidak mengandung keseluruhan Injil. Sebab itu arti dan dampak Injil seharusnya dipresentasikan ke budaya malu (shame culture) dan budaya takut (fear culture) secara yang lebih sesuai kepada pertanyaan dan kekhawatiran yang berlaku di dalam budaya itu. Kalau ciri khas setiap budaya dipahami dengan lebih teratur, maka juga dapat membaca Alkitab dan ajaran Injil dengan 'kacamata' atau 'lensa' yang lebih sesuai dengan kebutuhan budaya itu. Dengan cara ini berita keselamatan Injil Kristus akan bertambah kuat untuk meyakinkan para pendengar pekabaran Injil itu.
\end{abstract}

Keyword: Budaya bersalah, budaya malu, budaya takut, (re-)kontekstualisasi, konsep teologi tri-budaya, teologi perjanjian 


\section{Pendahuluan}

Dengan benar Alkitab diakui kaum Kristen sebagai Firman Allah yang menyatakan Injil Kristus sebagai jalan keselamatan bagi segala bangsa, suku, kaum dan bahasa (bdk. Why. 7:9). Kebenaran ini menuntun setiap orang Kristen ingin membaca Alkitab untuk mengerti isi Injil dan menerima petunjuk bagi kehidupannya. Tetapi, bersama dengan Filipus pada jalan dari Yerusalem ke Gaza, perlulah kita bertanya: "Mengertikah mereka apa yang mereka baca itu?" (Kis. 8:30). Karena makna dalam isi Alkitab tidak saja bergantung pada kemampuan membaca terjemahan Alkitab dalam bahasa yang tertentu, tetapi bergantung juga ke konteks dan latar belakang sang pembaca dan paling khusus budayanya. Sebab budaya berfungsi sebagai kacamata bagi isi berita yang tertulis.

Kemudian, kita sadar bahwa budaya sang pembaca tidak sama dengan budaya zaman Alkitab. Lebih lanjut, bahwa Alkitab sendiri memiliki perbedaan antara budaya dari waktu yang satu ke waktu yang lain, dan dari wilayah yang satu ke wilayah yang lain lagi. Misalnya, budaya yang berlaku pada zaman Abraham di tanah Kanaan akan berbeda dari budaya masyarakat Turki waktu Paulus hidup pada abad pertama. Mengabaikan konteks asli dan mengabaikan perbedaan itu dapat menyebabkan salah paham bagi sang pembaca. Sebab kalau budaya sang pembaca itu dianggap sebagai kerangka yang satu-satunya dan mutlak, maka isi Alkitab dipaksa menurut pengertian yang terbatas dan gampang keliru juga. Misalnya, tongkat Allah yang diangkat Musa dalam peperangan melawan orang Amalek (Kel. 17:8-13) dipahami oleh budaya yang satu ini sebagai tongkat yang bermuatan ajaib, sedangkan budaya yang lain akan memahaminya sebagai panji-panji atau bendera yang menguatkan para pahlawan secara psikologis, dan budaya lain lagi sebagai petunjuk strategis dalam konteks militer.

Walaupun sekarang kaum Kristen sadar tentang masalah ini dan bersedia menimbang pengertian dan interpretasi naskah Alkitab dari segi pelbagai budaya, hal itu belum diakui sama kuat di bidang teologis dan doktrin Kristen. Sebab budaya tertentu itu juga terbatas yang otomatis dalam hal memerhatikan seleksi naskah Alkitab yang tertentu akan kurang memerhatikan bahkan terkadang buta untuk melihat bagian Alkitab yang lain. Misalnya kenapa surat Paulus ke Roma itu dianggap lebih terutama daripada kitab Pengkhotbah, atau surat kepada Galatia itu dibahas paling lebih banyak daripada kitab Bilangan? Masalah interpretasi menjadi kendala besar di dalamnya.

Tanpa disadari pastilah terlintas alasan teologis yang benar dan berlaku untuk mengutamakan kepentingan kitab yang satu lebih daripada kitab yang lain, akan tetapi perlu juga memerhatikan secara kritis tentang latar belakang alasan teologis itu. Sebab kita yakin bahwa memang penulis Alkitab menyesuaikan beritanya dengan budaya tertentu pada zaman tertentu juga, namun bukan artinya bahwa ia setuju dengan segala aspek budaya yang berlaku pada saat itu. Artinya penyesuaian yang kritis, atau kontekstualisasi kritis menurut kebutuhan budaya dan konteks para pendengar atau pembaca yang pertama. Randolph Richards dan Brandon O'Brien dalam bukunya Misreading Scripture with Western Eyes menegaskan kepada pembacanya tentang betapa besar pengaruh budaya dan wawasan dunia kita kepada cara seseorang memahami Alkitab dan secara bersamaan berapa banyak hal yang terlewatkan ketika kita tidak menggabungkan perspektif mereka dari budaya lain. ${ }^{1}$

Ternyata dalam sejarah perkembangan kekristenan terdapat banyak perselisihan tentang ajaran Kristen yang berhubungan dengan masalah masyarakat, filsafat dan

${ }^{1}$ E. Randolph Richards dan Brandon J. O’Brien, Misreading Scripture with Western Eyes: Removing Cultural Blinders to Better Understand the Bible (Downers Grove: Inter-Varsity Press, 2012), 9-20. 
budaya zaman yang tertentu. Doktrin yang disebut 'Teologi Barat' itu menjadi kuat oleh bapak-bapak gereja yang hidup di Asia-Tengah, Mesir, Afrika-Utara, Yunani dan Italia, misalnya Agustinus. ${ }^{2}$ Lalu, baru kemudian aliran teologi di wilayah Eropa itu berkembang dengan perselisihan melawan penyimpangan ajaran Gereja Katolik Roma menjadi teologi menurut aliran reformasi, atau ajaran protestan. Ternyata ajaran ini disebarkan melalui pekabar Injil dari negara-negara barat, hingga di seluruh dunia ajaran reformasi ini diakui gereja-gereja protestan, baik yang disebut reformed, maupun yang dinamai Injili ataupun Pantekosta atau Kharismatik. Ini menjadikan awal masalah yang terus menjadi tantangan bagi setiap gereja untuk menerjemahkan Firman Tuhan kepada konteks berbeda-beda.

Tetapi, pertanyaan yang timbul ialah mengapa ajaran protestan yakin dengan sungguh-sungguh selaras dengan ajaran Alkitab dan harus dianggap sebagai satusatunya ajaran alkitabiah? mengapa terdapat banyak suku dan bangsa yang tidak merasa puas dengan ajaran protestan yang disebut Teologi Barat? Dalam artikel ini menjelaskan bahwa hal itu disebabkan oleh perspektif budaya yang berbeda-beda. Budaya yang tercipta karena usaha manusia dalam memahami subjek tertentu yang akhirnya menjadi kebudayaan di suatu wilayah tertentu. Misi gereja sepantasnya memerhatikan kajian-kajian budaya dari studi antropologi melaluinya dapat tersusun berbagai pendekatan yang sesuai. Perbedaan tersebut dapat diperhatikan berdasar kajian studi antropologi budaya. Dalam usaha memberikan penjelasan maka pada langkah berikutnya tulisan ini akan mengusulkan suatu cara pendekatan teologis yang lebih mengindahkan budaya dan konteks yang tertentu, bersifat introduksi, pendorong, usulan sementara dan percobaan untuk menerima tentangan agung ini, tanpa mengorbankan isi Injil Kristus yang universal dan yang dapat diakui oleh gereja di manapun di dunia ini. Pada akhirnya akan memberikan kesimpulan dari uraian yang dipaparkan

\section{Metode Penelitian}

Artikel ini menggunakan metode penyelidikan / riset literatur khususnya di bidang misiologi dan antropologi budaya. Sejauh dengan keyakinan bahwa kedua bidangnya memiliki keterkaitan dan keterlibatan yang saling memperjelas bagian-bagian tertentu untuk memahami konteks dan pendekatan yang akan digunakan oleh seorang misionaris. Dalam hubungannya tentang pertemuan dan keterlibatan menunjukkan interaksi sementara, dialogis, dan berpotensi transformatif di berbagai bidang teologi, dan menandai upaya untuk melampaui batas-batas subjek dengan memberikan pengertian lain pada kemungkinan memodelkan kembali praktik antropologi. ${ }^{3}$ Di samping itu, Hiebert menegaskan studi antropoligi budaya dapat membawa pemahaman konteks lintas budaya, menyediakan banyak wawasan bagi spesifik tugas misional. ${ }^{4}$

2 Roger E. Olson, The Story of Christian Theology: Twenty Century of Tradition \& Reform (Downers Grove: Apollos, 1999), 251-304. Jadi, sebenarnya istilah Teologi Barat kurang sesuai asalnya ajaran ini. Banyak bapak gereja yang bukan 'barat', hingga lebih baik sebut Teologi Tradisional dalam arti: Teologi yang diakui umum oleh semua gereja pada zaman itu dan bersifat berdasar ajaran asli.

3 Sin Wen Lau, Philip Fountain, and Derrick Lemons, "Anthropological Theologies : Engagements and Encounters," The Australian Journal of Anthropology 24, no. II (2014): 232.

4 Paul G. Hiebert, Anthropoligcal Insights for Missionaries, 24th ed. (Grand Rapids: Baker Academic, 2008), 15-16. 


\section{Pembahasan}

\section{A. Pengembangan teologi menurut budaya bersalah (guilt culture)}

Para penganut ajaran reformed dengan benar mengakui bahwa pergumulan Luther menemukan kembali arti Injil sebagai pembenaran orang berdosa hanya oleh iman. Karena kebenaran Injil telah diabaikan oleh ajaran Katolik Roma dengan segala macam penyimpangan dan formalitas yang tak spiritual. Tetapi, haruslah perhatikan kenapa Luther merasa terhibur dengan penemuan arti 'pembenaran oleh iman' dalam Roma 1:17.

Ternyata pergumulan Luther disebabkan ketakutannya untuk penghakiman murka Allah. Luther sangat yakin dan sadar bahwa ia seorang berdosa dan tidak dapat menyelamatkan dirinya, melawan ajaran Katolik Roma yang sebenarnya harap keselamatan oleh usaha dari pihak manusia atau dengan sekurang-kurangnya kerja sama Allah dan manusia dengan amalan agama. Memang, dengan benar Luther yakin akan ajaran tentang keselamatan kekal di Kerajaan Allah di bumi baru, tetapi juga ia mengaku kemungkinan akan hukuman kekal di tempat kutuk yang mengerikan. Kepercayaan akan kedua jalan itu biasa disingkatkan dengan istialah 'surga atau neraka' (bdk. Mzm. 1:6). Waktu Luther masih muda ia mengalami badai petir yang sangat hebat dan ia takut akan mati dan dihukum Allah dengan hukuman neraka. Sebab ketakutan yang sungguh-sungguh mendalam ini ia panggil Tuhan untuk melindunginya. Langsung ia mengangkat sumpah untuk menjadi biarawan dan menyerahkan hidupnya bagi Tuhan jikalau ia diselamatkan dari badai itu. ${ }^{5}$

Luther berpendapat bahwa harus meyakinkan Allah dengan pengorbanan dari pihak dia sendiri untuk menyelamatkannya. Akan tetapi, demi keselamatan ia banyak menunaikan kewajiban agama menurut gereja Katolik Roma, sebab ia tahu bahwa setiap hari, mau tak mau, ia bertambah dosa lain lagi, jadi betul-betul dalam hatinya merasa bersalah di hadapan Allah dan layak dihukum mati di neraka. Ia mengalami benarnya berita Alkitab bahwa sifat manusia sangat buruk. Justru karena Luther mengaku bahwa Allah seorang hakim yang sangat adil dan benar, maka ia mulai membenci Allah secara bersamaan. Jadi, dengan jerih payah dan hati yang sangat sedih ia menyelidiki Alkitab siang-malam dengan satu pertanyaan yang terpenting: 'Bagaimana saya dapat dibenarkan di hadapan Allah sehingga tidak dihukum mati di neraka?”

Lalu, ia membaca Mazmur 35:28, 'Dan lidahku akan menyebut-nyebut keadilan-Mu, memuji-muji Engkau sepanjang hari.' Dia tidak bisa mengerti kenapa penulis mazmur itu dapat memuji keadilan Allah. Sebab tak mungkin seorang manusia dapat memenuhi tuntutan keadilan itu. Baru kemudian ia membaca ulang Roma 1:16-17 (bdk. Hab. 2:4) dan salah satu saat yang tertentu, seperti kilat dalam pikirannya Luther mengerti: "Oleh iman orang percaya dihubungkan dan disatukan dengan Kristus dan dapat keadilan yang digenapkan Kristus di kayu salib. Kristuslah menjadi korban pendamaian bagi saya! Saya boleh bebas dari penghakiman dan dibenarkan di hadapan tribunal Allah! Haleluyah." Itulah hari kelahiran aliran Reformasi. Luther menyebut solusi yang heran ini bagi masalahnya dan pergumulannya: 'pertukaran yang menyenangkan'. ${ }^{6}$

\footnotetext{
5 Martin Brecht, "Martin Luther (1483-1546)," dalam Theologische Realenzyklopädie, Vol 21, ed. I. Leben (German: De Gruyter, 1991), 513.

${ }^{6}$ Luther dlm tafsiran ttg Gal 3:13 dengan terjemahan 'Kristus telah melepaskan kita dari hukuman Hukum Taurat oleh karena Dia dijadikan kutuk bagi kita'. Juga Luther menyebut anugerah ini 'pembebasan yang aneh'.
} 
Kemudian, ajaran ini juga tentulah dibenarkan oleh banyak nas Alkitab (mis. Rom 3:21-26; 5:1-11; 1Kor 1:30-31; Gal 3:1-14; 1Ptr 1:17-211Yoh 4:7-12). Ajaran ini diakui panjang lebar dalam surat-surat pengakuan reformasi, misalnya Katekismus Heidelberg pertanyaan-jawab 60:

\section{Pertanyaan. Bagaimana Saudara benar di hadapan Allah?} Jawab. Hanya oleh iman yang sejati kepada Yesus Kristus. Hati nuraniku memang mempersalahkan aku, karena aku berbuat dosa berat terhadap segala hukum Allah dan tidak ada yang kutaati, dan karena aku masih tetap cenderung pada segala macam kejahatan. Namun, Allah, tanpa jasa apa pun dari pihakku, semata-mata berdasarkan rahmat, memberikan kepadaku anugerah ini: pelaksanaan pelunasan oleh Kristus, kebenaran-Nya, dan kesucian-Nya yang sempurna dianggap-Nya sebagai milikku, seolah-olah aku belum pernah dihinggapi dosa atau berbuat dosa, bahkan seolah-olah aku sendirilah yang mengerjakan segala ketaatan yang dikerjakan oleh Kristus untukku, asal saja anugerah itu kuterima dengan hati yang percaya.

Oleh karena susah payah Luther dan pergumulan jiwanya dengan masalah dosa terhadap Allah dari perspektif penghakiman, maka jalanannya mencari solusi menghasilkan penemuan kembali (rediscovery) Injil sebagai Kabar Baik tentang anugerah Tuhan Allah. ${ }^{7}$ Karena Injil sesungguhnya sama sekali tidak menuntut segala macam amalan agama (seperti diajar gereja Roma), melainkan hanya minta penerimaannya dengan iman, dengan hati yang sungguh-sungguh percaya. Demikian lahirlah istilah reformasi yang termashyur: 'Dibenarkan oleh iman'.8 Demikian pertanyaan yang terpenting bagi Luther tentang apa arti Injil itu dijawab dengan pengertian baru tentang iman Kristen. Orang hanya dapat diselamatkan jikalau percaya dan harap sepenuh hati kepada Kristus yang disalibkan, dibangkitkan dan menjadi sang Pengantara bagi orang percaya di hadapan Allah di takhta-Nya (1Tim. 2:5-7) seperti juga tertulis dalam Roma 4:23-25:

Kata-kata ini, yaitu "hal ini diperhitungkan kepadanya," [-nya = Abraham] tidak ditulis untuk Abraham saja, tetapi ditulis juga untuk kita; sebab kepada kita pun Allah memperhitungkannya, karena kita percaya kepada Dia, yang telah membangkitkan Yesus, Tuhan kita, dari antara orang mati, yaitu Yesus, yang telah diserahkan karena pelanggaran kita dan dibangkitkan karena (atau: untuk) pembenaran kita.

Oleh sebab konsentrasi ajaran reformasi ke isu kebersalahan, utang karena dosa, penghakiman dan pendamaian berdasarkan penebusan utang dosa, dan Allah sebagai hakim termulia, maka konsep 'dibenarkan oleh iman' itu digolongkan sebagai 'sistem yuridis', atau 'injil forensis'. ${ }^{9}$ Demikian Katekismus Heidelberg dapat disebut surat pengakuan yang kerangkanya dominan itu bersifat yuridis.

7 Tj. Boersema, Het Evangelie Opnieuw Ontdekt: De Betekenis van Luther Voor de Reformatie van de Kerk (Groningen: De Vuurbaak, 1983), 39-53.

${ }^{8}$ Hans Burger, “'Evangelipresentatie En de Structuur van de Belijdenis,” Radix 27, no. 3 (2001): 180-182.

${ }^{9}$ Ibid., 182. 


\begin{tabular}{|l|l|}
\hline \multicolumn{2}{|c|}{ Ciri khas budaya bersalah (guilt culture) $\mathbf{1 0}^{\mathbf{1 0}}$} \\
\hline $\begin{array}{l}\text { Saya sudah langgar hukum dan } \\
\text { norma }\end{array}$ & $\rightarrow$ saya seorang yang tak sempurna dan malang \\
\hline $\begin{array}{l}\text { Hati nurani saya terbebani } \\
\text { negatif }\end{array}$ & $\rightarrow$ saya mengaku bahwa saya bersalah \\
\hline $\begin{array}{l}\text { Butuhan bagi keadilan dan } \\
\text { hukuman }\end{array}$ & $\begin{array}{l}\rightarrow \text { saya harus memenuhi utang dosa dan syarat } \\
\text { pendamaian }\end{array}$ \\
\hline Pertanyaan terpenting & $\begin{array}{l}\text { Bagaimana saya bisa dibebaskan dari utang } \\
\text { kesalahanku? }\end{array}$ \\
\hline Dengan kata lain & APA ARTI INJIL DALAM MASALAH INI ?? \\
\hline $\begin{array}{l}\text { Jawab reformasi (Luther / } \\
\text { Calvin) }\end{array}$ & Dibenarkan oleh kepercayaan kepada Kristus \\
\hline
\end{tabular}

Jadi, sebagai kesimpulan dapat dikatakan bahwa sifat dan karakter seorang di budaya bersalah itu menerima keselamatan sebagai pemulihan hubungan dengan Allah yang memuaskan kekhawatiran hati nuraninya. Dan demikian juga Injil dan usaha Kristus ditafsir dari perspektif pengadilan. Untuk Roland Muller sebagaimana dikutip oleh Geoff menjelaskan jika sumber prioritas yang diberikan dalam beberapa budaya untuk bersalah dan tidak bersalah ditemukan dalam gagasan Barat atas hukum, yang berakar pada kode dalam kitab Imamat dan Bilangan dari Perjanjian Lama, Hukum Romawi, dan Hukum Yunani. ${ }^{11}$ Ini membawa perbedaan hak dan salah dan karenanya merupakan dasar untuk bersalah dan tidak bersalah. Muller menegaskan bahwa nilainilai ini berkontribusi pada doktrin dan praktik-praktik Gereja dan, melalui penyebaran Gereja, untuk budaya Barat. ${ }^{12}$

\begin{tabular}{|l|l|}
\hline \multicolumn{2}{|c|}{ Arti keselamatan menurut budaya bersalah (guilt culture) ${ }^{\mathbf{1 3}}$} \\
\hline Sifat keselamatan & Ruang pengadilan $\rightarrow$ yuridis \\
\hline Pertanyaan pokok & Bagaimana saya diampun dan dibebaskan dari hukuman? \\
\hline Allah & Hakim yang paling adil dan benar \\
\hline Keadilan & Menurut hukum kriminal \\
\hline Yesus & Pengganti bagi saya oleh korban pendamaian-Nya di salib \\
\hline Kayu salib & Alat hukuman $\rightarrow$ Amarah Allah dipadamkan korban Yesus \\
\hline Murid Yesus & Ketaatan untuk melayani Yesus \\
\hline Etik & Cinta kasih $\rightarrow$ disampaikan kepada sesama manusia \\
\hline
\end{tabular}

\section{B. Peran ajaran reformasi dalam usaha misi di seluruh dunia}

Penemuan kembali Injil oleh aliran reformasi itu menimbulkan semangat gereja untuk mengabarkan Injil semakin luas, terutama di wilayah Eropa sendiri. Sebab wilayah Eropa sudah ratusan tahun bersama Katolik Roma. Biar banyak orang bukan Kristen, namun pemerintahan negara dan gereja bekerja sama untuk mengatur politik,

10 Penjelasan detail lih. Lampiran 1

11 Geoff Beech, "Shame/Honor, Guilt/Innocence, Fear/Power in Relationship Contexts," International Bulletin of Mission Research 42, no. 4 (2018): 340.

12 Ibid.

${ }^{13}$ Lihat penjelasan lebih lanjut di Georges, Jayson, The 3D Gospel, New York: Time Press: 2014) dan Werner Mischke, The Global Gospel: Achieving Missional Impact in Our Multicultural World, Arizona: Mission One, 2015). 
baik dan buruk. Sebab itu daerah Eropa dianggap sudah dikristianisasi, dan dianggap wilayah Kristen. Hasil politik itulah banyak orang memang merasa takut untuk meninggal dunia dan masuk neraka kalau tidak memenuhi syarat peraturan gereja, antara lain amalan baik, pembayaran bagi doa syafaat bagi orang yang telah meninggal, pengharapan dalam Maria dan ikut sakramen yang diatur pejabat gerejani. Dengan begitu banyak orang merasa sangat takut bagi Tuhan sebagai hakim dan meraguragukan akan keselamatannya yang kekal.

Usaha misi dari pihak gereja reformasi bersifat bentuk penginjilan kembali (reevangelisation) bagi banyak wilayah di Eropa, khususnya bagian Eropa-Utara. Karena sejak saat itu semakin banyak orang mengerti ajaran Alkitab bahwa pelunasan utang dosanya telah dipenuhi Kristus di kayu salib sehingga mereka mulai pasti dalam iman dan bergembira tentang Injil sebagai Kabar Baik yang meyakinkan akan kehidupan kekal secara sungguh-sungguh.

Kemudian, sejak pertengahan abad ke-XVI itu gereja reformasi mengutus para misionaris ke kontinen yang lain di luar Eropa, khususnya Amerika-Utara, Afrika dan Asia, termasuk Indonesia. ${ }^{14}$ Misi memang berhasil di banyak tempat, banyak orang bertobat dan banyak gereja didirikan. Sekarang banyak gereja di segala kontinen yang ikut ajaran reformasi dengan senang hati dan mereka juga setuju dengan surat-surat pengakuan reformasi sebagai ajaran dasar gereja Kristen sedunia.

Akan tetapi, makin lama makin lebih gereja Kristen juga mengalami bahwa ajaran reformasi semakin diterima secara resmi, namun juga timbul perasaan umum bahwa ajaran ini, walau sungguh-sungguh menurut Alkitab, kurang masuk hati dan pikiran orang Kristen di wilayah non-barat. ${ }^{15}$ Ada yang berkata bahwa kekristenan itu diangkut sebagai pohon yang harus ditanam kembali di tanah wilayah non-barat. Ternyata akar pohon itu hampir-hampir tidak masuk dalam ke dalam tanah yang lain itu. Hasilnya bahwa pohon kekristenan itu mulai kering dan tidak menghasilkan buah banyak. Juga banyak orang tidak merasa tertarik oleh pengakuan reformasi itu dan tidak ingin bertobat. Mereka mengaku bahwa ajaran ini tidak relevan bagi masalah religius yang dialaminya dan menyebut ajaran Kristen itu 'agama asing', bahkan di Indonesia terkadang-kadang juga dianggap sebagai 'agama Belanda'. Dengan demikian, hasil misi dan penginjilan sangat terbatas di wilayah Asia, dan juga di Indonesia.

Sebagai refleksi tentang keadaan ini dapat menyimpulkan dua kemungkinan: 1) orang Asia dan juga orang Indonesia yang tidak ingin bertobat itu melawan kehendak Allah dengan keras hati sehingga usaha misi terus berkembang supaya menyakinkan orang bahwa setiap manusia perlu bertobat dan percaya kepada Kristus. Atau kemungkinan lain: 2) Injil sebagai Kabar Baik tidak dikabarkan sesuai dengan pengertian dan perasaan spiritulitas pendengar Asia. Dengan kata lain, Injil tidak diarahkan ke budaya yang berlaku di wilayah non-barat dan belum disesuaikan dengan situasi dan konteks yang baru. Kemudian muncullah pertanyaan bagaimana harus mengurus penyesuaian pekabaran Injil bagi budaya yang non-barat?16

14 Kees Haak, "Reformed Means Mission," last modified 2019, accessed September 20, 2021, https://www.academia.edu/29362503/Reformed_means_mission.

15 Lamin Saneh, Whose Religion Is Christianity?: The Gospel beyond the West (Grand Rapids: Eerdmans, 2003), 85-70.

${ }^{16}$ Bdk dengan masalah yg disebut 'kontekstualisasi', mis. David J. Hesselgrave \& Edward Rommen, Contextualization: Meanings, Methods, and Models, Grand Rapids: Baker Book House, 1989, hlm 39-126. 


\section{Tiga jenis budaya yang diakui universal ${ }^{17}$}

Dalam hal ini kita sangat mengindahkan sumbangan dan pengertian dari pihak ilmu antropologi budaya. ${ }^{18}$ Pada umumnya dapat dikatakan adanya tiga jenis budaya yang berlaku di mana-mana: 1) budaya takut, 2) budaya malu, dan 3) budaya bersalah. ${ }^{19}$ Memang, terdapat banyak variasi dalam ketiga jenis itu, tetapi setiap budaya mengaku ketiga unsur ini sebagai struktur yang paling dasar. Ketiga nama dari budaya menyatakan sifatnya secara pendek, demikian:

1) Budaya takut (fear culture) menunjukkan sifat dan perasaan dasar sebagai 'ketakutan' (fear) dari segi negatif, dan harus ditambah dengan istilah bagi segi yang positif. Biasanya istilah 'kekuatan', atau mungkin 'daya' (power) digunakan. Jadi: ketakutan - kekuatan. ${ }^{20}$

2) Budaya malu (shame culture) menunjukkan sifat orang yang 'merasa malu' (shame). Itulah segi yang negatif dari perasaan itu. Kata yang sebaliknya pada umumnya ialah 'hormat' (honor), yaitu sikon bahwa si orang yang malu akan dihormati orang lain dan sebab itu tidak perlu merasa malu lagi. ${ }^{21}$ Jadi: malu hormat

3) Budaya bersalah (guilt culture) menunjukkan keadaan orang yang melanggar hukum, kebenaran dan keadilan sehingga ia layak untuk diadili dan dihukumkan menurut peraturan yang diakui sah (guilt). Kata yang menunjuk baliknya ialah 'benar', 'tidak bersalah' (innocence), 'dibebaskan dari tuduhan atau hukuman'. Si orang yang dibebaskan dari tuduhan 'bersalah' itu boleh keluar ruang pengadilan waktu hakim sudah putus 'tak bersalah'. Jadi: bersalah - tak bersalah, atau: bersalah - benar.

Pada umumnya dapat dikatakan bahwa ketiga jenis budaya ini memengaruhi segala budaya, tetapi bukan secara yang sama atau dengan tekanan yang sama kuat. Sehingga isu tentang hal tersebut telah menjadi perhatian dalam lingkup misi. ${ }^{22}$ Ciri khas wilayah atau bangsa yang satu itu dikuasai secara dominan dengan budaya takut, sedang budaya malu bersifat dominan bagi wilayah dan negara yang lain lagi, dan

17 Pada bagian ini penulis banyak terpengaruh oleh pandangan-pandangan dari Jayson Georges, The 3D Gospel; Paul Hiebert, Anthropological Insights for Missionaries, Grand Rapids: Baker Book, 1985; David J. Hesselgrave, Communicating Christ Cross-Culturally, Grand Rapids: Zondervan, 1978; Charles H. Kraft, Christianity in Culture, New York: Orbis Books, 1981; bdk. Geert Hofstede, Cultures and Organizations: Software of the Mind, New York: McGraw-Hill Education, 2010.

18 Paul G. Hiebert, Transforming Worldviews: An Anthropological Understanding of How People Change (Grand Rapids: Baker Academic, 2008).

${ }^{19}$ Jayson Georges, The 3D Gospel: Ministry in Guilt, Shame, and Fear Cultures (New York, 2016), 1115.

20 Namun, dapat menimbangkan koreksi sedikit dengan usulan: 'ketakutan - ketenangan'. Sebab dari pihak negatif kata ketakutan menyatakan perasaan batin. Kalau ingin menyebut segi positif seharusnya juga menunjuk suasana batin lagi, jadi ketenangan lebih seimbang daripada kekuatan. Biar juga dapat diakui bahwa orang yang dibantu atau diiringi dengan kekuatan pastilah juga akan dapat ketenangan batin. Jadi, biar istilah yang dipakai pada umumnya kurang tepat, maka demi penyesuaian vokabuler artikel ini menggunakan 'ketakutan- kekuatan'.

21 Sama seperti catatan kaki di atas ini kata 'hormat' sebenarnya tidak menunjuk baliknya dari 'perasaan malu'. Sebab perasaan malu berada di dalam batin dan keinsafan si orang malu, jadi kata yang membaliknya seharusnya kena batin dan insaf juga. Mungkin kata 'kebanggaan' (pride) yang positif itu lebih baik. Tetapi artikel ini akan menggunakan 'hormat' untuk menyesuaikan dengan vokabuler umum.

${ }^{22}$ Johannes Merz, "The Culture Problem: How the Honor/Shame Issue Got the Wrong End of the Anthropological Stick," Missiology: An International Review 48, no. 2 (2020): 10-11. 
kemudian daerah dan suku berikut sangat didominasi oleh budaya bersalah. ${ }^{23}$ Seperti terlihat pada ilustrasi seluruh dunia dapat digolongkan secara kasar ke dalam tiga wilayah, ${ }^{24}$ demikian:

- $\quad$ Budaya takut: kontinen Afrika dan Amerika-Selatan (Latin America), tetapi juga bagian Indonesia yang paling timur, Papua New Guinea dan AustraliaUtara

- $\quad$ Budaya malu: seluruh wilayah kontinen Asia, termasuk Asia Minor, Eropa-Selatan, Korea dan Jepang

- Budaya bersalah: kontinen Eropa (khususnya bagian barat) dan kontinen Amerika-Utara

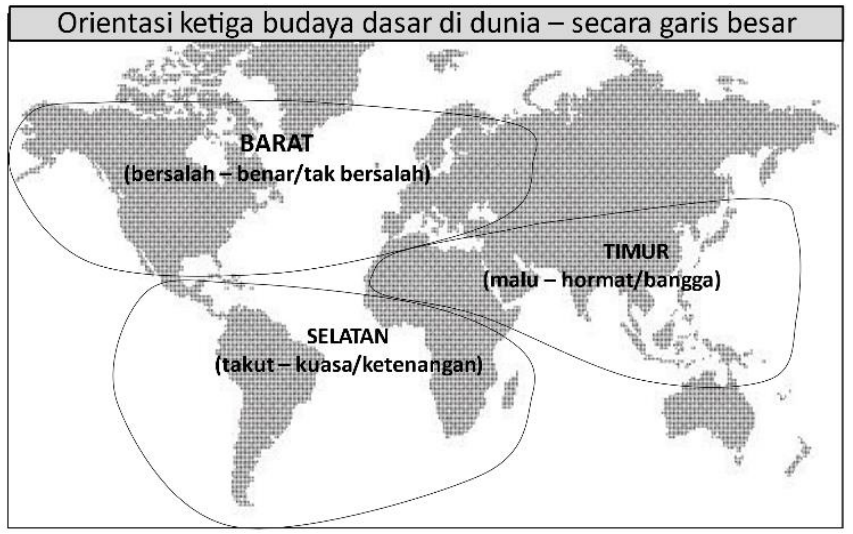

Berulang kali ditekankan bahwa sketsa tersebut masih tentatif, bisa berubah dari waktu ke waktu. Misalnya, di kontinen Eropa dan Amerika-Utara pengaruh budaya bersalah mulai kurang sedang kuasa budaya malu bertambah kuat. Sebaliknya, terdapat bagian di kontinen Asia (termasuk Indonesia) pengaruh budaya bersalah muncul dengan lebih kuat daripada zaman dahulu.

Dalam peta terlihat bahwa budaya kontinen Eropa dan Amerika-Utara yang dipengaruhi oleh agama Kristen dan Injil dikontesktualisasikan sesuai dengan budaya bersalah, walau juga harus mengaku bahwa mungkin juga budaya bersalah itu sendiri dipengaruhi dan dibentukkan oleh aliran Kristen Protestan. Sebaliknya kontinen Asia yang pada umumnya agama Muslim, Hindu dan Konfusius. Rupanya ketiga agama itu dipengaruhi budaya malu dan hampir tidak memberikat kesempatan bagi agama Kristen Protestan.

Ternyata kontinen Afrika dan Latin-Amerika sangat dipengaruhi budaya takut, namun di wilayah itu juga banyak pengaruh agama Kristen yang bersifat aliran Pantekosta dan kharismatik. Mungkin hal itu berarti bahwa ajaran Kristen Protestan (yang ikut Luther dan Calvin) lebih sesuai dengan budaya barat juga (atau sebaliknya), tetapi bahwa wilayah budaya malu agak tertutup untuk menerima Injil Kristus yang ikut protestan. Bahkan aliran pantekosta dan kharismatik itu juga agak berbeda dari ciri khas aliran protestan dan reformasi.

Gambaran dan tinjauan ini mendorong pertanyaan tentang keberpihakan (onesidedness) ajaran protestan dalam interpretasi Injil dengan ciri khas 'dibenarkan oleh iman'. Biar aliran itu sepenuh-penuhnya alkitabiah dan harus diakui dengan segenap hati, namun dapat dikatakan bahwa teologi reformasi itu bukanlah refleksi sempurna tentang Injil. Gereja dan teologinya, misi dan pendekatannya harus terus terpanggil menggali Alkitab juga dari segi budaya malu dan budaya takut. Sama sekali hal itu tidak berarti bahwa ajaran Kristen harus tunduk kepala kepada budaya ini atau itu, sebab Alkitab mengeritiki segala budaya saat yang bersamaan. Tetapi artinya bahwa alangkah

23 Simon Cozens, "Shame Cultures, Fear Cultures, and Guilt Cultures: Reviewing the Evidence," International Bulletin of Mission Research 42, no. 4 (2018): 327-328.

${ }^{24}$ Beech, "Shame/Honor, Guilt/Innocence, Fear/Power in Relationship Contexts," 340-41. 
baiknya gereja, teologi dan misiologi berusaha menyesuaikan diri - secara kritis - lebih ke budaya takut dan malu.

\section{Injil sebagai Kabar Baik bagi budaya malu (shame culture)}

\begin{tabular}{|l|l|}
\hline \multicolumn{2}{|c|}{ Ciri khas budaya malu (shame culture) } \\
\hline $\begin{array}{l}\text { Saya sudah kehilangan } \\
\text { identitasku }\end{array}$ & $\rightarrow$ saya ingin menyembunyikan diri bagi orang lain \\
\hline $\begin{array}{l}\text { Saya yakin saya tak berguna } \\
\text { apa-apa }\end{array}$ & $\begin{array}{l}\rightarrow \text { saya ingin dihormati orang lain dan bisa bangga } \\
\text { diri }\end{array}$ \\
\hline $\begin{array}{l}\text { Hati nurani berdasarkan orang } \\
\text { lain }\end{array}$ & $\begin{array}{l}\rightarrow \text { saya presentasiakan diri sesuai kesukaan orang } \\
\text { lain }\end{array}$ \\
\hline Pertanyaan terpenting & $\begin{array}{l}\text { Bagaimana saya bisa mendapat respek dan rasa } \\
\text { bangga diri }\end{array}$ \\
\hline Dengan kata lain & APA ARTI INJIL DALAM MASALAH INI ?? \\
\hline $\begin{array}{l}\text { Jawab ikut kontekstualisasi ke } \\
\text { malu }\end{array}$ & $\begin{array}{l}\text { Dianugerahkan identitas baru dalam persekutuan } \\
\text { Kristus }\end{array}$ \\
\hline
\end{tabular}

Jikalau mulai membaca Alkitab dengan kaca mata dari budaya malu, maka mendapat banyak informasi yang boleh digunakan dan disistematisasikan. Konsep kehormatan dan rasa malu sulit bagi orang-orang Kristen Barat dengan nilai-nilai individualistis untuk dipahami. Untuk memahami nilai sentral kehormatan dan rasa malu, dan fungsinya dalam teologi, kita membutuhkan model antropologis yang mampu menafsirkan data. Seperti semua model, berikut ini adalah peta konseptual yang sengaja mengurangi interworking budaya yang kompleks ke dalam pola yang bermakna untuk menganalisis budaya dan teks Alkitab. ${ }^{26}$

\section{Perjanjian Lama}

- Kejadian 2:25 dan 3:7-10. Tuhan menciptakan manusia pria dan wanita. Biar mereka telanjang mereka tak rasa malu. Tapi sesudah berdosa terutama mereka merasa malu dan menyembunyikan diri. Jadi, hal rasa takut mendahului mengaku bersalah.

- Hal malu berhubungan dengan nama, hormat dan kemuliaan. Musa mengerti bahwa Tuhan ingin dihormati dan tidak dipermalukan di hadapan bangsabangsa (Kel. 32:9-14). Justru kemuliaan Allah (God's glory) sifat yang terpenting bagi Allah, dan Allah ingin dipuji segala bangsa (bdk. Kel. 32:4-6).

- Rut diterima dalam persekutuan umat Tuhan sebagai hasil integrasi ke dalam perjanjijan anugerah. Bahkan, Rut sangat dihormati dengan anaknya (Rut 4:1322), sebagai tahap berikut silsilah Yesus (Mat. 1:2).

- Daud yang dianggap hina oleh kakaknya, dimuliakan Tuhan dan menjadi Raja Agung bagi Israel, biar ia harus menderita banyak. Sebaliknya, waktu ia bergembira dan menari-nari di hadapan Tuhan ia tidak merasa malu, sedangkan isterinya Mikhal menegur Daud oleh karena merasa malu baginya, seorang raja yang menari-nari dalam baju yang sangat sederhana. Tuhan sendiri

25 Penjelasan detail lihat Lampiran

26 Jayson Georges, "From Shame to Honor: A Theological Reading of Romans for Honor-Shame Contexts," Missiology: An International Review 38, no. 3 (2010): 297. 
membalikkan pendapat dengan memalukan Mikhal hingga tak dapat anak (2Sam. 6:11-23).

- Banyak Mazmur mengaku realitas yang memalukan, terutama Mazmur. 22 (bdk. 40:16; 69:8.20; 89:46; 132:18. Tuhan menjamin bahwa orang yang berharap akan Dia tak pernah akan dipermalukan (Mzm. 25:2-3.20; 31:2.18). Kemudian, juga Tuhan sendiri ingin dihormati dan dimuliakan. Kemuliaan Tuhan itulah juga kebanggaan umat-Nya.

\section{Perjanjian Baru}

- Silsilah Tuhan Yesus menggambarkannya dengan kemuliaan yang tertinggi (Mat. 1).

- Banyak perselisihan antara ahli Taurat dengan Yesus bersifat perjuangan untuk mempermalukan Yesus, sedangkan setiap kali Yesus membalikkan situasi dan sangat dihormati rakyat (mis. Mat. 7:28-29; 9:26; 12:10-21; 21:12-17; 22:4146).

- Dalam perumpamaan unsur budaya malu itu sangat kuat. Si anak yang hilang itu (Luk. 15) sangat dipermalukan oleh majikan dengan kerja bagi babi (yang dilarang bagi orang Yahudi!) tetapi yang diterima kembali dengan ayahnya dan dapat cincin dan pakaian sebagai anak yang sah dan dimuliakan. Demikian gambar dari Yesus sendiri yang ingin supaya manusia dilepaskan dari rasa malu dan dapat kembali identitasnya.

- Proses melawan Yesus dalam Yohanes 18-20 hanya dapat dipahami kalau mengerti sistem mempermalukan dan dimuliakan. Justru orang yang ingin menghinakan Yesus (mis. ahli Taurat dan Pilatus) sehingga Yesus disalibkan menghasilkan bahwa mereka itu malu waktu Yesus mati sebagai pemenangan atas rencana Iblis, dan juga waktu Ia bangkit dari kubur.

- Doa Yesus di Getsemani menyatakan bahwa Ia bersedia dimuatkan dengan rasa malu manusia untuk mengabsorsi perasaan itu dalam kematian-Nya. Penderitaan Yesus yang sangat mempermalukan Dia, secara telanjang di kayu salib, membuktikan bahwa Ia mengambil rasa malu dari orang percaya dan menghilangkannya ke dalam kematiaan-Nya sehingga tak perlu rasa malu lagi bagi orang yang harap kepada Yesus.

- Seluruth riwayat Yesus menyatakan bahwa Ia berhasil justru karena Ia bersedia untuk dipermalukan, sampai ke kayu salib. Tetapi justur melalui jalan itu Tuhan meninggikan Yesus dengan nama atas segala nama (Flp. 2:5-11).

Sebagai kesimpulan ajaran Alkitab juga menunjuk realitas dari rasa malu karena gagalnya rencana manusia, kesulitan dalam relasi, kurang apresiasi untuk dirinya sendiri, pengasingan, perasasan ketinggalan. Injil memberikan harapan kepada orang yang malu bahwa mereka diterima kembali sebagai anak yang diadopsi Tuhan dalam persekutuan dan relasi dengan Tuhan, dengan umat-Nya, bahwa mereka dapat bergembira karena dipulihkan, disembuhkan, direstorasi dan ditransformasi oleh Roh Kristus.

Pemulihan relasi dengan Allah juga mengandung janji bahwa terjalinnya relasi dengan sesama, dengan dirinya sendiri dan dengan semesta alam akan diperbaiki dan mengalami restorasi. Demikian Injil tentang Kristus memulai lagi sejarah yang baru untuk mengganti kerusakan relasi waktu Adam dan Hawa menghancurkan relasi dengan 
Allah, Penciptanya. Oleh kepercayaan kepada Kristus seluruh kehidupan akan diperbarui dan merefleksikan maksud Allah dengan kaum manusia di bumi ini.

Dengan kata lain: Injil sebagai Kabar Baik bagi budaya malu berarti bahwa manusia boleh menjadi manusia sejati lagi, bahwa terdapat relasi yang dipulihkan, bahwa identitasnya diakui sesungguhnya, tidak perlu membenci diri akan tetapi berdiri sebagai manusia yang utuh dan hormat menurut kehendak Allah dan merasa bangga diri secara yang murni. Sebab Allah bukan saja hakim, tetapi juga seorang bapak yang mengasihi, mengampuni, menerima kembali dalam persekutuan-Nya yang akrab. Oleh kepercayaan orang dapat menerima kebanggaan akan dirinya sendiri karena yakin sudah diintegrasikan lagi ke dalam persekutuan yang karib dengan Allah oleh Kristus.

\begin{tabular}{|l|l|}
\hline \multicolumn{2}{|c|}{ Arti keselamatan menurut budaya malu (shame culture) (27 $^{\mathbf{7}}$} \\
\hline Sifat keselamatan & Integrasi dalam persekutuan $\rightarrow$ relasionil \\
\hline Pertanyaan pokok & Bagaimana dapat hormat $\rightarrow$ identitas utuh dan bangga diri \\
\hline Allah & Bapak yang menyayangi \\
\hline Keadilan & Kesetiaan menurut sumpah perjanjian anugerah \\
\hline Yesus & Pengantara sebagai kakakku \\
\hline Kayu salib & Alat cinta kasih $\rightarrow$ relasi dengan Allah dipulihkan dan aman \\
\hline Murid Yesus & Loyalitas dengan rasa bangga karena kakakku termulia \\
\hline Etik & Hormat $\rightarrow$ mengindahkan identitas sesama manusia \\
\hline
\end{tabular}

\section{E. Injil sebagai Kabar Baik bagi budaya takut (fear culture)}

Perasaan takut itu bersifat universal dan menimbul ke dalam hati setiap orang. Biar ada orang yang merasa diri sangat kuat, mereka juga terancam oleh segala macam bahaya, baik yang natural, seperti kekerasan oleh orang lain, ataupun oleh kekhawatiran tentang masa depan, maupun bahaya atau kuasa yang supranatural dan yang tak kelihatan atau yang tak dapat dipahami dan tak dapat dikontrol. Wilayah ketakutan yang bersifat psikologis dan spiritual itu sangat luas. Ada alasan untuk sungguh-sungguh waspada terhadap bahaya dan boleh takut kena malapetaka. Akan tetapi ada juga ketakutan yang tak beralasan atau alasan yang tak perlu ditakui. Ternyata istilah bahwa banyak orang takut bagi bahaya yang tak pernah akan muncul. Demikian mereka dimuat dengan beban berat yang sebenarnya sia-sia. Kehidupannya menderita karena kekurangan memahami realitas semesta alam.

Tetapi, dari segi lain, adanya manusia yang dengan benar insaf akan kuasa-kuasa di dunia yang tak kelihatan dan adanya pengaruh yang tak dapat dimanipulir. Hal itu biasa diakui di bidang spirituil, misterius dan keagamaan. Sebab banyak orang mengaku adanya kuasa ajaib, roh-roh jahat, nenek moyang yang sudah meninggal dunia tetapi yang masih mengganggu orang yang hidup dengan kutuk atau berkat. Tentu, juga orang Kristen mengaku kuasa yang tak kelihatan dari pihak Iblis yang ingin memengaruhi kaum manusia dan menghancurkan pendamaian, keamanan, kebahagiaan dan kesejahteraan di dunia. 
Secara garis besar dapat mendeskrispsi budaya takut demikian

\begin{tabular}{|l|l|}
\hline \multicolumn{2}{|c|}{ Ciri khas budaya takut (fear culture) $\mathbf{2 8}$} \\
\hline $\begin{array}{l}\text { Saya sadar akan kuasa-kuasa } \\
\text { ajaib }\end{array}$ & $\begin{array}{l}\rightarrow \text { saya takut sebagai bola mainan yang dilempar } \\
\text { sembarangan }\end{array}$ \\
\hline $\begin{array}{l}\text { Saya terlemah, rentan, tak } \\
\text { mampu }\end{array}$ & $\begin{array}{l}\rightarrow \text { saya harap hidup stabil oleh keseragahan untuk } \\
\text { control }\end{array}$ \\
\hline $\begin{array}{l}\text { Saya bereksistensi di tingkat } \\
\text { kosong }\end{array}$ & $\rightarrow$ saya harap keseimbangan kuasa-kuasa kosmis \\
\hline Pertanyaan terpenting & $\begin{array}{l}\text { Di mana terdapat sikon aman dan ketenangan } \\
\text { jiwaku? }\end{array}$ \\
\hline Dengan kata lain & APA ARTI INJIL DALAM MASALAH INI ?? \\
\hline $\begin{array}{l}\text { Jawab ikut kontekstualisasi ke } \\
\text { takut }\end{array}$ & $\begin{array}{l}\text { Kepastian kemenangan Pemenang Kristus atas } \\
\text { Iblis dan maut }\end{array}$ \\
\hline
\end{tabular}

Alkitab sangat sadar akan situasi dan kondisi manusia di bawah kolong langit. Banyak kali perasaan takut diakui dan disebut sebagai realitas bagi jiwa orang yang terganggu di dunia yang dirusakkan dosa manusia.

\section{Perjanjian Lama}

- Kejadian 3:10, waktu Adam dan Hawa berdosa dan mereka sadar akan pertemuan dengan sang Penciptanya mereka pertama-tama merasa takut. Biar mulai dengan merasa malu dan menyembunyikan diri, baru waktu mereka sadar akan kehadiran Allah, bersifat sesuatu 'kuasa' yang spiritual, mereka rasa takut. Mereka tidak tahu bagaimana harus mengontrol situasi ini. Sejak waktu itu hal 'takut' muncul dalam hati orang (bdk. Kain, Kej. 4:14) selalu harus waspada tentang apa yang bisa jadi secara tiba-tiba.

- $\quad$ Perasaan takut hadir di mana-mana di dunia: Umat Israel sangat takut waktu Tuhan turun di bukit Horeb (Kel. 19:16.18 dan 20:18-21); Gideon sadar bahwa banyak orang pasti takut untuk berperang jadi ia minta mereka pulang saja (Hak. 7:3), dan banyak mengaku takut; raja Saul takut untuk roh jahat (1Sam. 16:14-15; bdk 18:15); kalau orang tidak ikut hikmat yang terdapat dalam peraturan menurut kehendak Tuhan maka mereka akan didatangi kedahsyatan dan kecemasan (Ams. 1:27); juga raja-raja Israel yang kurang setia kepada Tuhan sangat takut bagi bahaya serangan raja-raja negara lain (mis. Yes. 7:2).

- $\quad$ Dalam kitab Mazmur banyak kali menyatakan ketakutannya dan berteriak kepada Tuhan untuk menyelamatkannya (Mzm. 18:7; 25:17.22; 31:25; 69:18; 88 (seanteronya, tapi khusus ay. 16-19); 107:6.13.19.28; 116:3.11; 120:1) dan lain-lain.

- Tetapi banyak kali juga pemazmur mengaku bahwa Tuhan mampu menyelamatkannya dari ketakutan dan dari bahaya ancaman. Mazmur yang paling disukai orang percaya ialah Mazmur 23 dan 63. Orang percaya merasa diri aman dan tenang di bawah perlindungan dan tindakan Allah sebagai gembala yang agung. Seperti domba beristirahat di padang yang berumut

28 Penjelasan detail lih Lampiran 1 
hijau dan sungai air segar, maka demikian orang yang takut menjadi tenang dan boleh beristirahat. Janji inilah seperti garis merah di seluruh Alkitab.

\section{Perjanjian Baru}

- $\quad$ Alkitab sangat terbuka tentang kekhawatiran dan ketakutan kaum manusia. Juga orang yang percaya dapat mengalami ketakutan yang dahsyat, misalnya Petrus dan murid lain (Mat. 8:25, bdk. Mrk. 4:38; Luk. 8:24, Mat. 14:30).

- Apa yang paling menarik perhatian ialah bahwa juga Yesus sendiri mengalami ketakutan yang sangat berat (Mat. 26:38). Ia sadar akan penderitaan yang terngeri dan terdahsyat, jadi sebagai manusia yang sungguhsungguh bersifat manusia Ia gentar untuk masuk ke dalam siksaan dan murka

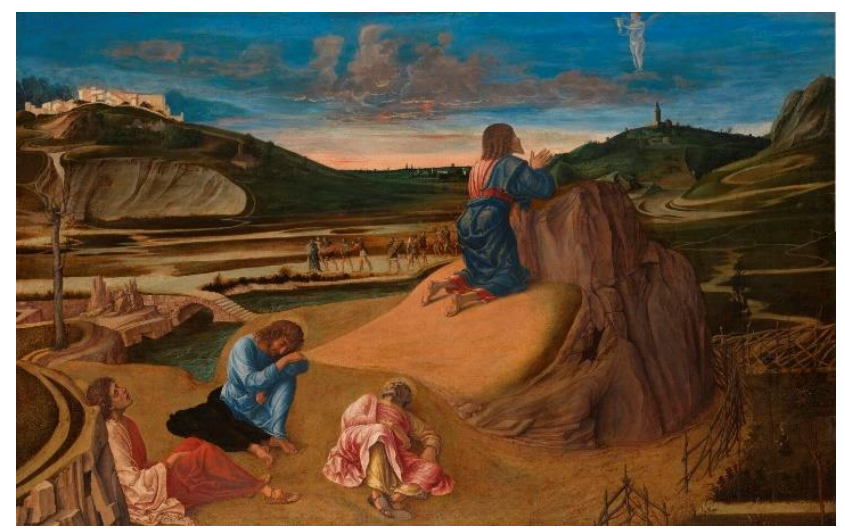
Allah. Namun, biar takut Ia ingin menyerahkan diri-Nya ke rencana Allah Tritunggal sejak kekal untuk menyelamatkan dunia. Dalam ketakutan-Nya Yesus menyatakan kasih-Nya yang luar biasa bagi kaum manusia dengan maju terus pada jalan penderitaan. Keputusan inilah bersifat kunci untuk membuka masa depan dan pendirian Kerajaan Allah. Peristiwa dan doa Yesus di Getsemani adalah titik balik bagi sejarah dunia.

- $\quad$ Kebangkitan dari kematian menyatakan bahwa Yesus mengalahkan kuasa maut dan rencana Iblis, seperti dijanji dalam Kejadian 3:15. Oleh kemenangan itu Tuhan Yesus meyakinkan orang percaya bahwa tidak perlu takut lagi bagi kuasa-kuasa apapun. Bahkan Ia telah mempermalukan Iblis dan tentaranya (Kol. 2:15) dengan menjadikan mereka sebagai tontonan di muka umum, dan di seluruh dunia.

- $\quad$ Pasti juga orang Kristen dapat mengalami ketakutan seperti nyata dalam surat Paulus, Ibrani dan 1 Petrus. Penganut Yesus dianiaya dan dipenjarakan, tetapi mereka dihiburkan untuk tak pernah lelah atau menyerah iman, sebab Kristus telah mengalahkan dunia (Yoh 16:33, bdk. Ef. 6:10- 20; Kol. 1:24-29; 2Tim. 3:12; Ibr. 10:32-39; 1Ptr. 3:8-12; 4:12-19).

- Teristimewa kitab Wahyu menyatakan banyak bahaya dan ancaman dari pihak Iblis dan kuasanya yang jahat hinga umat Tuhan gampang ditakuti. Tetapi kepastian tentang kemenangan Kristus itu menghiburkan orang percaya dalam penderitaannya, bdk kata Yesus agar jangan takut sebab Ialah yang hidup untuk selama-lamanya dan memegang kunci maut dan kerajaan maut (Why. 1:17-18). Demikian kaum Kristen, sebagai manusia biasa, pasti mengalami ketakutan bagi bermacam-macam bahaya dan ancaman (mis. Why. 12-13) namun mereka tetap bertahan percaya - biar dalam penjara, seperti dalam riwayat hidup Paulus dan banyak orang kristen dalam sejarah - dan dikuatkan oleh perspektif kemenangan akhir pada Hari Kiamat.

Kesimpulan tentang Injil sebagai Kabar Baik untuk budaya takut bersifat penghiburan yang sangat kuat, sebab Kristus adalah Pemenang, Viktor, Pahlawan yang mengalahkan Iblis dan maut dengan penderitaan-Nya di salib dan kebangkitan-Nya dari 
kematian. Ia hidpu untuk selama-lamanya dan mampu melindung umat-Nya melawan serangan Iblis. Bahkan, orang percaya dapat bertahan dalam ancaman, kekerasan, penjara dan mautpun, sebab mereka akan hidup bersama-sama dengan Kristus. Itulah sebabnya kaum Kristen dikenal sebagai orang yang mempunyai harapan (Kis. 23:6; 26:7; 28:20; Rom. 5:5; 8:24; 12:12; Kol. 1:5.23.27; 1Ptr. 1:3; 3:15). Kitab Wahyu seanteronya menyatakan harapan dan kekuatan bagi orang percaya sebab peperangan melawan Iblis dan dunia yang jahat itu akan berhasil: Kristus Pemenang yang Mahamulia (Why. 19:11-16). Yesus Kristus inilah 'Raja segala raja dan Tuan di atas segala tuan'.

\begin{tabular}{|l|l|}
\hline \multicolumn{2}{|c|}{ Arti keselamatan menurut budaya takut (fear culture) } \\
\hline Sifat keselamatan & Suasana peperangan lawan penguasa ajaib $\rightarrow$ militer \\
\hline Pertanyaan pokok & $\begin{array}{l}\text { Mana tempat dan sikon terkontrol agar jiwaku } \\
\text { tenang? }\end{array}$ \\
\hline Allah & $\begin{array}{l}\text { Tuhan, Sang mahakuasa untuk memerintah } \\
\text { universum }\end{array}$ \\
\hline Keadilan & $\begin{array}{l}\text { Keseimbangan kuasa-kuasa ajaib yang menjamin } \\
\text { kepastian }\end{array}$ \\
\hline Yesus & $\begin{array}{l}\text { Penakluk yang kosmis, Viktor = Pemenang atas Iblis } \\
\text { dan maut }\end{array}$ \\
\hline Kayu salib \& kebangkitan & $\begin{array}{l}\text { Tempat dan alat bagi proklamasi kemenangan } \\
\text { Kristus }\end{array}$ \\
\hline Murid Yesus & $\begin{array}{l}\text { Takluk diri kepada Pahlawan Kristus dalam } \\
\text { balatentara-Nya }\end{array}$ \\
\hline Etik & Memberkati $\rightarrow$ kaum manusia di seluruh dunia \\
\hline
\end{tabular}

\section{F. Teologi perjanjian / kovenantal sebagai konsep penyatu bagi tiga budaya $^{29}$}

Demi pelayanan bagi gereja oikumenis dan misi sedunia teologi dan misiologi ditantang untuk mengembangkan konsep atau kerangka teologis yang relevan bagi ketiga budaya yang dominan itu. Dalam hal ini dapat merefleksi tentang ajaran tentang perjanjian anugerah. Sifat perjanjian anugerah itu terbuka untuk menerima segala bangsa, suku dan budaya dengan mengindahkan identitasnya masing-masing. Sebab gereja yang universal sebagai umat perjanjian itu juga bersifat multikultural dan multibahasa karena Tuhan tidak selektif atau mengistimewakan satu bangsa, suku, bahasa, budaya daripada semua yang lain. Peraturan dan perlindungan perjanjian menjamin pemenuhan dan pemuasan keinginan dan kekhawatiran segala bangsa.

- Budaya takut diperhatikan dalam hal bahwa Kristus baik pengantara perjanjian tetap sekaligus Pemenang, Viktor, yang merebut kembali dari tangan Iblis kuasa dan kewibawaan atas hidup dan mati. Oleh Kristus perjanjian didasarkan realitas fakta sejarah, salib dan kebangkitan, yang membalikkan nasib dan masa depan sejarah dunia. Orang yang termasuk

${ }^{29}$ Untuk penjelasan lebih jauh lihat, Cornelis J. Haak, "Covenant of Grace: Introduction to and Mainlines of the Relationship between God and Man \& the Structural Power for Mission," Bahan Ajar, last modified 2019, https://www.academia.edu/53077389/Covenant_of_Grace_SAAT. 
dalam perjanjian diberkati dengan kesentosaan dan ketenangan jiwa bahwa hidup mereka aman dan stabil untuk selama-lamanya.

- $\quad$ Budaya malu dihormati dengan upaya Kristus yang mengabsorpsi perasaan malu dari pengikut-Nya yang dianggap sebagai adiknya, sedang Ialah bersifat kakak yang tertinggi dan termulia. Murid Kristus diadopsi ke dalam perjanjijan dengan hak yang sah sebagai adik-adik-Nya. Pengetahuan dan kepercayaan bahwa Yesus Kristus mengaku dan sudah menderita pengalaman yang hina dan malu yang sama dengan murid-Nya itu memberikan kembali identitas dan kebanggaan akan manusia sendiri. Segala relasi dipulihkan dan manusia boleh berjalan di dunia ini sebagai orang yang berdiri teguh dan kegembiraan terhadap Allah, sesama manusia dan persekutuan Kristen dalam jemaat, terhadap dirinya sendiri dan terhadap dunia dan konteks semesta alam.

- Budaya bersalah diakui dalam hal pembenaran dan pendamaian yang diusahakan Kristus waktu berdoa di Taman Getsemani waktu disalibkan dan memanggil ketertinggalan-Nya oleh Allah-Nya, kemudian oleh kebangkitanNya, pengangkatan-Nya ke Surga dan doa-Nya syafaat di hadapan Allah Bapa pada takhta-Nya di Surga. Hasil usaha-Nya memuaskan baik sifat kasih dan sifat keadilan Allah sehinga dosa diampuni dan orang percaya dibebaskan dari hukuman mati kekal dan boleh hidup di pelataran kerajaan Allah sebagai orang yang dibebaskan dari penjara kematian. Demikian mereka diperlengkapi berlaku lagi sebagai anak Allah untuk mempresentasi Penciptanya di dunia ini dalam segala usaha dan kerja mereka yang tak bisa sia-sia lagi (1Kor. 15:58).

Konsep penyatu digambarkan secara ringkas dalam ilustrasi di bawah ini:

\begin{tabular}{|l|l|l|l|l|}
\hline \multicolumn{5}{|c|}{ Variasi dalam konsep teologis } \\
\hline $\begin{array}{c}\text { Kerangka } \\
\text { konsep }\end{array}$ & $\begin{array}{c}\text { Budaya takut } \\
\text { pragmatis }\end{array}$ & $\begin{array}{c}\text { Budaya malu } \\
\text { Sintetis }\end{array}$ & $\begin{array}{l}\text { Budaya bersalah } \\
\text { analitis }\end{array}$ & $\begin{array}{c}\text { Konsep } \\
\text { penyatu }\end{array}$ \\
\hline Epistemologis & $\begin{array}{l}\text { Terkesan oleh } \\
\text { subjek } \\
\text { Pengetahuan } \\
\text { emosionil } \\
\text { Teologi } \\
\text { emosionil }\end{array}$ & $\begin{array}{l}\text { Relasi ke subjek } \\
\text { Pengatahuan } \\
\text { relasionil } \\
\text { Teologi } \\
\text { relasionil }\end{array}$ & $\begin{array}{l}\text { Jarak terhadap } \\
\text { subjek } \\
\text { Pengatahuan } \\
\text { akademis } \\
\text { Teologi } \\
\text { sistematis }\end{array}$ & $\begin{array}{l}\text { Teologi } \\
\text { kovenantal }\end{array}$ \\
\hline $\begin{array}{l}\text { Orientasi } \\
\text { yang } \\
\text { dominan }\end{array}$ & $\begin{array}{l}\text { Orientasi } \\
\text { kekuatan } \\
\text { Pertemuan } \\
\text { kekuatan-2 } \\
\text { (peperangan } \\
\text { rohani) }\end{array}$ & $\begin{array}{l}\text { Orientasi } \\
\text { relasionil } \\
\text { Sensitif kepada } \\
\text { respek } \\
\text { Persekutuan } \\
\text { (dialog } \rightarrow\end{array}$ & $\begin{array}{l}\text { Orientasi } \\
\text { pengetahuan } \\
\text { Pertemuan } \\
\text { pengetahuan } \\
\text { Keyakinan } \\
\text { rasionil } \\
\text { (apologetik) }\end{array}$ & $\begin{array}{l}\text { Orientasi } \\
\text { iman yang } \\
\text { hidup } \rightarrow \\
\text { martirik }\end{array}$ \\
& $\begin{array}{l}\text { Teologi yg } \\
\text { besarkan hati }\end{array}$ & $\begin{array}{l}\text { Teologi } \\
\text { berceritera }\end{array}$ & $\begin{array}{l}\text { Teologi } \\
\text { ekspositiri }\end{array}$ & $\begin{array}{l}\text { Teologi } \\
\text { biblikal }\end{array}$ \\
\hline Genre / jenis & $\begin{array}{l}\text { Tradisi sebagai } \\
\text { petunjuk } \\
\text { hemeneutis }\end{array}$ & $\begin{array}{l}\text { Komunitas } \\
\text { sebagaik norma } \\
\text { hermeneutis }\end{array}$ & $\begin{array}{l}\text { Individualisme } \\
\text { sebagai } \\
\text { kreativitas }\end{array}$ & $\begin{array}{l}\text { Hermenetik } \\
\text { dalam } \\
\text { komunitas }\end{array}$ \\
\hline Hermeneutik
\end{tabular}




\begin{tabular}{|l|l|l|l|l|}
\hline & & & hermeneutis & $\begin{array}{l}\text { dan } \\
\text { konsultasi } \\
\text { jemaat }\end{array}$ \\
\hline Etis & $\begin{array}{l}\text { Etik respek dan } \\
\text { hormat } \\
\text { Etik } \\
\text { kewaspadaan }\end{array}$ & $\begin{array}{l}\text { Etik situasionil } \\
\text { (Re- } \\
\text { Jkontekstualisasi }\end{array}$ & $\begin{array}{l}\text { Etik ikut hukum } \\
\text { / Yuridis } \\
\text { Etik normatif }\end{array}$ & $\begin{array}{l}\text { Etik } \\
\text { kovenantal }\end{array}$ \\
\hline
\end{tabular}

\section{Kesimpulan}

Budaya yang beragam tercipta karena usaha dari berbagai manusia dalam memahami subjek tertentu yang akhirnya menjadi kebudayaan di suatu wilayah tertentu. Situasi ini menimbulkan lahirnya budaya-budaya yang semakin jauh dari budaya pada zaman Injil. Sebagai panggilan dan tugas gereja menyatakan kebenaran Injili, misi gereja sepantasnya memerhatikan juga kajian-kajian budaya dari studi antropologi melaluinya dapat tersusun berbagai pendekatan yang sesuai. Berbedaan antara beberapa kontinen di dunia memberikan gambaran yang bisa memainkan peran sentral dalam pemberitaan Injil. Budaya takut (fear culture) akan memiliki pandangan berbeda dengan budaya malu (shame culture) dalam melihat kabar baik, dan seterusnya. Artikel ini merupakan sebuah kontribusi awal bagi dunia teologi di Indonesia yang masih perlu diteruskan.

\section{Referensi}

Beech, Geoff. "Shame/Honor, Guilt/Innocence, Fear/Power in Relationship Contexts." International Bulletin of Mission Research 42, no. 4 (2018): 338-346.

Boersema, Tj. Het Evangelie Opnieuw Ontdekt: De Betekenis van Luther Voor de Reformatie van de Kerk. Groningen: De Vuurbaak, 1983.

Brecht, Martin. "Martin Luther (1483-1546)." In Theologische Realenzyklopädie, Vol 21, edited by I. Leben. German: De Gruyter, 1991.

Burger, Hans. "Evangelipresentatie En de Structuur van de Belijdenis.” Radix 27, no. 3 (2001): 170-190.

Cozens, Simon. "Shame Cultures, Fear Cultures, and Guilt Cultures: Reviewing the Evidence." International Bulletin of Mission Research 42, no. 4 (2018): 326-336.

Georges, Jayson. "From Shame to Honor: A Theological Reading of Romans for HonorShame Contexts." Missiology: An International Review 38, no. 3 (2010): 295-307.

-_- The 3D Gospel: Ministry in Guilt, Shame, and Fear Cultures. New York, 2016.

Haak, Cornelis J. "Covenant of Grace: Introduction to and Mainlines of the Relationship between God and Man \& the Structural Power for Mission." Bahan Ajar. Last modified 2019. https://www.academia.edu/53077389/Covenant_of_Grace_SAAT.

Hiebert, Paul G. Anthropoligcal Insights for Missionaries. 24th ed. Grand Rapids: Baker Academic, 2008.

- - - Transforming Worldviews: An Anthropological Understanding of How People Change. Grand Rapids: Baker Academic, 2008.

Kees Haak. "Reformed Means Mission." Last modified 2019. Accessed September 20, 2021. https://www.academia.edu/29362503/Reformed_means_mission. 
Lau, Sin Wen, Philip Fountain, and Derrick Lemons. "Anthropological Theologies: Engagements and Encounters." The Australian Journal of Anthropology 24, no. II (2014): 227-234.

Merz, Johannes. "The Culture Problem: How the Honor/Shame Issue Got the Wrong End of the Anthropological Stick." Missiology: An International Review 48, no. 2 (2020): 127-141.

Olson, Roger E. The Story of Christian Theology: Twenty Century of Tradition \& Reform. Downers Grove: Apollos, 1999.

Richards, E. Randolph, and Brandon J. O'Brien. Misreading Scripture with Western Eyes: Removing Cultural Blinders to Better Understand the Bible. Downers Grove: InterVarsity Press, 2012.

Saneh, Lamin. Whose Religion Is Christianity?: The Gospel beyond the West. Grand Rapids: Eerdmans, 2003. 